Dvulit Zoriana, Doctor of Economics, Associate Professor, Professor of the Department of Foreign Economic and Customs Activities, Lviv Polytechnic National University, Lviv, Ukraine

ORCID ID: 0000-0002-2157-1422

e-mail: zdvulit@ukr.net

Zlotnik Marta, student, Lviv Polytechnic National University, Lviv, Ukraine

e-mail: martazlotnik@gmail.com

\title{
Perspective sources of small and medium business financing in Ukraine
}

Abstract. Introduction. The article investigates the role of small and medium-sized businesses and its financing in the development of Ukraine's economy and describes some perspective financing sources, which can lead to increasing the efficiency of small and medium business activity. Purpose. To highlight the main problems in financing of small and medium-sized businesses in Ukraine and to develop proposals and recommendations for its solution with the help of modern untraditional sources of financing of enterprises. Results. The literature sources, statistical data, official web portals related to the chosen topic are analyzed. The main obstacles of doing business in the country are analyzed, the main sources of financing for small and medium-sized enterprises are identified, such as internal financing, bank loans, repurchase agreements, bond issues, commercial lending. The features of bank lending, interest rates of leading Ukrainian banks and the system of state support to small and medium-sized businesses are described, the main disadvantages of using the traditional financing sources are highlighted. Alternative types of financing sources for enterprises such as leasing, venture funding, factoring are considered, nonconventional structures for Ukrainian small and medium businesses, such as business incubators and business angels, are investigated. The programs of international financial organizations that are implemented in Ukraine to support small and medium business are analyzed. The key problems of financing of small and medium business in Ukraine are highlighted. Conclusions. The priority directions of financing development for increase of efficiency of activity of small and average business in Ukraine are suggested. The measures to improve the state support of Ukrainian business are recommended.

Keywords: small and medium business; financing; bank lending; state support for small businesses; international financial organizations; alternative sources of financing; business angels; business incubators.

\section{удК 658.14}

Двуліт 3. П., доктор економічних наук, доцент, професор кафедри зовнішньоекономічної та митної діяльності, Національний університет «Львівська політехніка», м. Львів, Україна

ORCID ID: 0000-0002-2157-1422

e-mail: zdvulit@ukr.net

Злотнік М. Л., студентка, Національний університет «Львівська політехніка», м. Львів, Україна

e-mail: martazlotnik@gmail.com

\section{Перспективні джерела фінансування малого і середнього бізнесу в Україні}

Анотація. Розвиток малих та середніх підприємств відіграє важливу роль у розвитку всієї економіки країни. Сьогодні малі та середні підприємства в Україні мають обмежені можливості для перетворення прибутку в додатковий капітал. Основними проблемами таких підприємств є брак оборотних коштів або відсутність стартового капіталу. Через ці перешкоди існує необхідність залучення додаткових джерел фінансування. Метою даної статті є висвітлення основних проблем фінансування малого та середнього бізнесу в Україні та розробка пропозицій щодо їх вирішення за допомогою перспективних джерел фінансування для підприємств. В статті досліджено роль малого і середнього бізнесу в розвитку економіки України, проаналізовано основні перешкоди для ведення бізнесу в країні, виділено основні джерела фінансування малих та середніх підприємств, особливості банківського кредитування та системи державної підтримки малого бізнесу. Розглянуто альтернативні види джерел фінансування для підприємств, досліджено діяльність нетрадиційний для українського малого $i$ середнього бізнесу структур фінансування, таких як бізнес-інкубатори та «ангели бізнесу». Виділено ключові проблеми фінансування малого та середнього бізнесу в Україні. Проаналізовано програми міжнародних фінансових організацій, які реалізуються в Україні для підтримки малого і середнього бізнесу. Запропоновано пріоритетні

Стаття надійшла до редакції: 03.10.2018

Received: 03 October 2018 
напрями розвитку фінансування для підвищення ефективності діяльності малого та середнього підприємництва в Україні.

Ключові слова: малий та середній бізнес; фінансування; банківське кредитування; державна підтримка малих підприємств; міжнародні фінансові організації; альтернативні джерела фінансування; ангели бізнесу; бізнес-інкубатори.

Formulation of the problem. The development of small and medium-sized enterprises plays an important role in the development of the whole country's economy. Nowdays, small and medium-sized business entities in Ukraine have limited opportunities for turning profits into additional capital. The main problems of such enterprises are shortage of working capital or lack of start-up capital. Due to these obstacles, there is a need to attract additional sources of funding.

Analysis of recent research and publications. The problems connected with sources of financing for small and medium-sized businesses are considered in the works of such scientists as Poloven O. [1]; Rumyantseva S. [2]; Bogun K. [3]; Buryak P. [4] and others. Problems of state financial and credit support of small business have been highlighted by such domestic scientists as Kondratyuk $\mathrm{T}$. [5], Frankiv O.; Strychak G. [6].

It should be noted that studies of domestic and foreign scholars are more focused on the analysis of internal sources of funding and programs of state support to small and medium businesses. The problems of bank lending and the prospects of using modern alternative sources of funding need further research, which emphasizes the relevance of the article.
The aim of the study. The purpose of this article is to highlight the main problems in financing small and medium-sized businesses in Ukraine and to develop proposals for their solution with the help of perspective sources of financing for enterprises.

The main part. Small and medium-sized businesses are an integral part of the socio-economic system of the country because it provides a comparable stability of market relations due to its flexibility in the non-volatile environment. It should be noted that domestic small and medium business units have not yet taken their place in line with the world experience of market transformations. One of the problems hindering the development of small and medium-sized businesses in Ukraine is, first of all, the lack of financial resources for its effective functioning. In addition, there are many other factors that slow down the development of small and medium businesses.

According to a survey conducted within the framework of the World Economic Forum, a report on the global competitiveness of each country was formed. In this rating Ukraine ranks 81st among 137 possible. The annual report The Global Competitiveness Index 2017-2018 [7] highlights the main factors that have the most negative impact on doing business in Ukraine (Fig. 1).

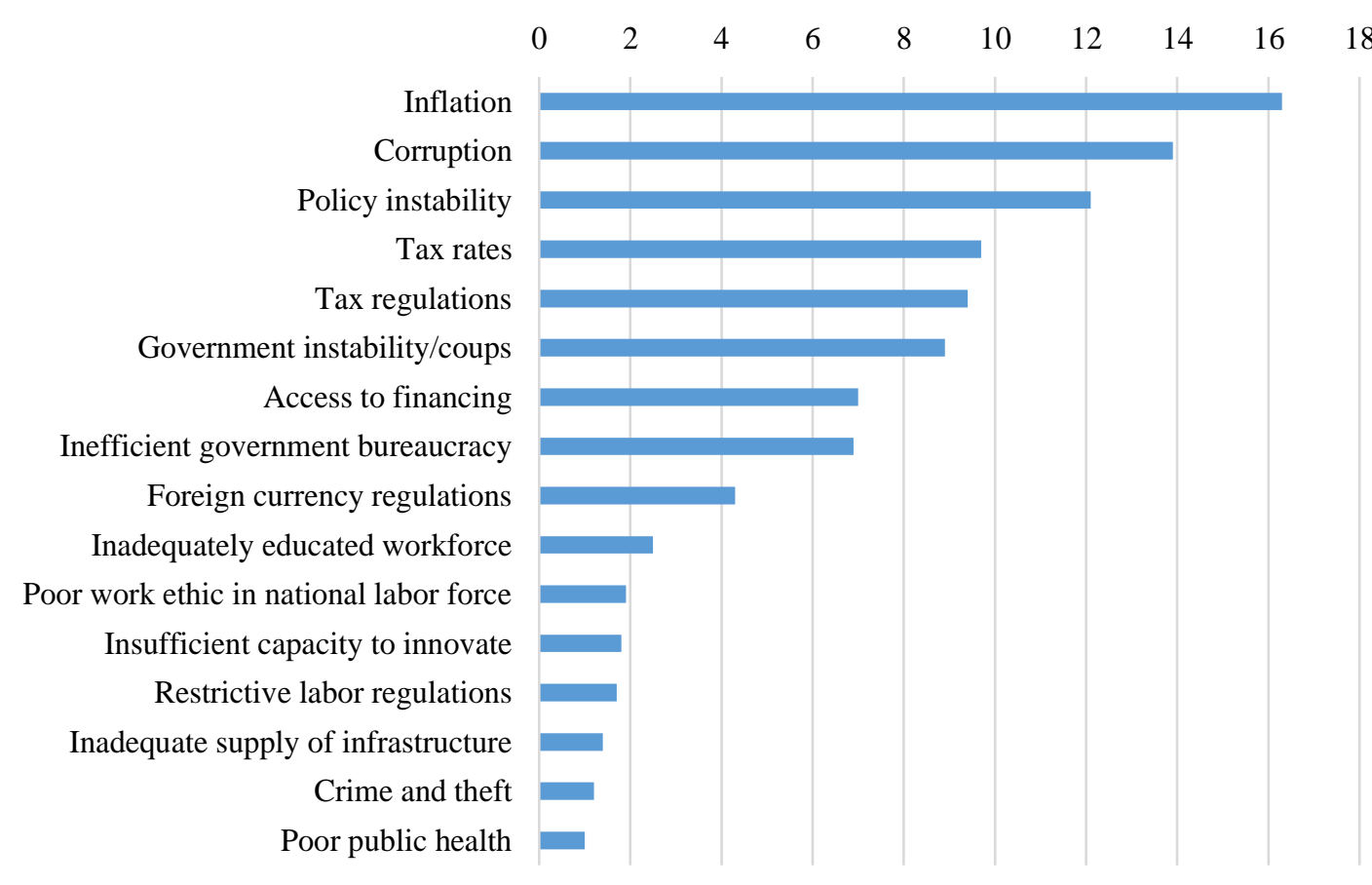

Figure 1 - The main problems of doing business in Ukraine

Source: Global Competitiveness Report 2017-2018 [7] 
Inflation, corruption and political instability are the most acute problems that Ukrainian business cannot withstand. From the data obtained, the components of global competitiveness of Ukraine appears (Table 1), according to each of which our country is significantly lagging behind the leading states.

Table 1 Components of the Global Competitiveness Index of Ukraine for 2017-2018

\begin{tabular}{|l|c|}
\hline \multicolumn{1}{|c|}{ Indicators } & $\begin{array}{c}\text { Ukraine's place in the } \\
\text { world }\end{array}$ \\
\hline Global Competitiveness Index & 81 \\
\hline Subindex A: Basic requirements & 96 \\
\hline 1st pillar: Institutions & 118 \\
\hline 2nd pillar: Infrastructure & 78 \\
\hline 3rd pillar: Macroeconomic environment & 121 \\
\hline 4th pillar: Health and primary education & 53 \\
\hline Subindex B: Efficiency enhancers & 70 \\
\hline 5th pillar: Higher education and training & 35 \\
\hline 6th pillar: Goods market efficiency & 101 \\
\hline 7th pillar: Labor market efficiency & 86 \\
\hline 8th pillar: Financial market development & 120 \\
\hline 9th pillar: Technological readiness & 81 \\
\hline 10th pillar: Market size & 47 \\
\hline Subindex C: Innovation and sophistication factors & 77 \\
\hline 11th pillar: Business sophistication & 90 \\
\hline 12th pillar: Innovation & 61 \\
\hline
\end{tabular}

Source: [7]

Most of the listed factors are not able to be influenced at the moment, but many indicators can be improved by facilitating the financing of small and medium-sized enterprises. After all, their activity is the driving force of raising the level of innovation, technology, skills of employees, market efficiency, etc.

Small and medium-sized enterprises are largely using traditional internal and external sources of funding. As a result of the analysis of literary sources [3], the following main sources of funding for enterprises were identified:

1) internal resources (financing from retained earnings, pre-capitalization or bank loan under the owner's deposit, etc.).

This type of financing is ineffective at the initial stages of business development due to lack of profits and working capital, dependence on suppliers, high tax rates and the impossibility to use a depreciation fund due to rapid inflation.

2) traditional bank lending

This type of financing is the most common in Ukraine, but there are many obstacles to obtaining loans, namely high interest rates, tight credit history, the first installment requirements, and significant additional fees. One of the reasons for lending to small and medium-sized businesses in Ukraine is also the lack of information transparency that banks and financial institutions need to assess credit risk.

In order to deepen the analysis of the bank loans market for small and medium-sized businesses, the lending rates for replenishment of working capital of the enterprise of leading Ukrainian banks [8-15] were investigated (Table 2).

Table 2 Interest rates on loans for small businesses proposed by leading Ukrainian banks in 2018

\begin{tabular}{|l|c|c|c|}
\hline \multirow{2}{*}{ Banks } & \multicolumn{3}{|c|}{ Interest rates, \% } \\
\cline { 2 - 4 } & UAH & USD & EUR \\
\hline Privatbank & 20 & 8,5 & 8,5 \\
\hline Raiffeisen Bank Aval & 20,2 & 7,5 & 7 \\
\hline Credit Agricole & 19,85 & 7,33 & 6,33 \\
\hline Kredobank & 20,25 & 6,25 & 5 \\
\hline PUMB & 20,74 & 9,24 & 8,24 \\
\hline Ukreximbank & 22,22 & 8,72 & 7,82 \\
\hline Ukrsibbank & 18,75 & 5,74 & 3,9 \\
\hline Oshchadbank & 17,86 & 10,86 & 9,86 \\
\hline
\end{tabular}

Source: [8-15] 
So, with choosing any of the banks, Ukrainian businessmen are forced to pay about $20 \%$ for loans, which is an unusually high rate compared to the rates of European banks, which reach $2-5 \%$. To date, there have been some positive developments in this direction, banks offer significant reduction of loan rates for special needs, for example, for companies planning activities related to alternative energy sources, etc.

3 ) issuance of corporate bonds on the domestic or foreign market, the initial public offer, etc.

Since the Ukrainian stock market is currently underdeveloped, this kind of financing is practically not used, especially for small enterprises.

4) commercial lending - prepayment of goods by customers and installment payment to suppliers.

This kind of lending is quite widespread, but it involves significant risks. A high degree of dependence on suppliers and customers can lead to a crisis of non-payment in the case of payment delays for commercial loans, which could result in the bankruptcy of the enterprise.

5) repurchase agreement (REPO) is a loan provided by securities owned by the company, with the transfer of ownership of these securities to the creditor for the period of crediting.

In Ukraine, REPO transactions are carried out with a limited range of securities. Often, REPO transactions involve bonds of issuers issued in large volumes and circulating in the secondary market. In particular, these companies are about 20 emitters of the "first echelon", which means, they are inaccessible to small and mediumsized businesses. The counterparty and issuer's risks in the REPO market are the default of the counterparty or the issuer. Their minimization is carried out by analyzing and monitoring the financial position of counteragents and issuers, as well as setting limits on transactions with them [16].

6) factoring, leasing, project financing, export financing, venture funds, etc.

The following sources of financing are an important alternative to traditional lending. And if in Europe such methods of financing business activity are the norm, then in Ukraine they are used relatively rarely. This negative tendency is explained both by political and economic factors. The obstacles to the development of nontraditional sources of financing in Ukraine are the lack of qualified specialists who can professionally serve potential users; lack of sufficient information on the specifics of alternative sources of funding, their advantages, and disadvantages, engagement mechanisms; lack of clear legislation on modern sources of funding.

International lending programs that are currently operating successfully in Ukraine may also be alternate sources of financing. By analyzing the official web portals [17-22], the most important of them were identified (Table 3).

Table 3 International financial organizations operating in Ukraine

\begin{tabular}{|c|c|c|}
\hline $\begin{array}{l}\text { International financial } \\
\text { organizations }\end{array}$ & Name of the program & Description \\
\hline \multirow[t]{5}{*}{$\begin{array}{l}\text { International Finance } \\
\text { Corporation [17] }\end{array}$} & $\begin{array}{l}\text { Ukraine Sustainable Energy } \\
\text { Finance Program }\end{array}$ & $\begin{array}{l}\text { Financial and business support, activities related to energy } \\
\text { efficiency }\end{array}$ \\
\hline & $\begin{array}{l}\text { Ukraine Resource Efficiency } \\
\text { Program }\end{array}$ & $\begin{array}{l}\text { Strengthening the investment in enterprises that use and develop } \\
\text { resource-saving technologies. }\end{array}$ \\
\hline & $\begin{array}{l}\text { Ukraine Residential Energy } \\
\text { Efficiency Project }\end{array}$ & $\begin{array}{l}\text { Modernization of the residential sector with the use of alternative } \\
\text { energy technologies. }\end{array}$ \\
\hline & $\begin{array}{l}\text { Ukraine Agri-Insurance } \\
\text { Development Project }\end{array}$ & $\begin{array}{l}\text { Support and development of agribusiness insurance, funded with } \\
\text { the support of the Ministry of Foreign Affairs, Trade and } \\
\text { Development of Canada. }\end{array}$ \\
\hline & Ukraine Agri-Finance Project & $\begin{array}{l}\text { Agribusiness financing and agricultural support in Ukraine, } \\
\text { consulting on the potential of agribusiness. }\end{array}$ \\
\hline \multirow[t]{2}{*}{$\begin{array}{l}\text { European Bank for } \\
\text { Reconstruction and } \\
\text { Development (EBRD) [18] }\end{array}$} & $\begin{array}{l}\text { The Eastern Partnership SME } \\
\text { Finance Facility }\end{array}$ & $\begin{array}{l}\text { Lending for small and medium-sized businesses in the context of } \\
\text { the financial crisis for enterprises with a state of less than } 250 \\
\text { people, whose period of activity does not exceed } 2 \text { years. }\end{array}$ \\
\hline & EBRD & $\begin{array}{l}\text { Lending to business in Ukraine regardless of size for enterprises } \\
\text { whose activities are related to the development of IT consulting, } \\
\text { marketing, European accounting standards, foreign trade } \\
\text { activities. }\end{array}$ \\
\hline \multirow[t]{2}{*}{$\begin{array}{l}\text { German- Ukrainian Fund } \\
\text { [19] }\end{array}$} & Microlending Program & $\begin{array}{l}\text { Financing of services, trade, agribusiness for microenterprises, } \\
\text { individuals - entrepreneurs or medium-sized businesses. The size } \\
\text { of the loan can reach } € 25,000 \text { - } € 250,000 \text { for period of } 3 \text { - } 5 \text { years. }\end{array}$ \\
\hline & $\begin{array}{l}\text { Agri-sector Refinancing } \\
\text { Program }\end{array}$ & $\begin{array}{l}\text { Financing of production, agribusiness, trade and service for small } \\
\text { and medium businesses in an area where the population does not } \\
\text { exceed } 100000 \text {. The maximum loan is } € 250000 \text { for period of } 3-5 \\
\text { years. }\end{array}$ \\
\hline
\end{tabular}




\begin{tabular}{|l|l|l|}
\hline $\begin{array}{l}\text { German government- } \\
\text { owned development } \\
\text { bank (KfW) [20] }\end{array}$ & $\begin{array}{l}\text { European Fund for Southeast } \\
\text { Europe }\end{array}$ & $\begin{array}{l}\text { Financing and concessional conditions for agriculture, fisheries, } \\
\text { food industry, small hotels development, green tourism, } \\
\text { restaurant business, light industry, energy efficiency projects, as } \\
\text { well as projects for increasing productivity in underdeveloped } \\
\text { regions. Loans range from } € 100000 \text { to } € 300000 .\end{array}$ \\
\hline $\begin{array}{l}\text { Competitiveness of } \\
\text { Enterprises and Small } \\
\text { and Medium-sized } \\
\text { Enterprises (COSME) [21] }\end{array}$ & $\begin{array}{l}\text { Erasmus for Young } \\
\text { Entrepreneurs, European } \\
\text { Strategic Cluster } \\
\text { Partnerships, European } \\
\text { Destinations of Excellence }\end{array}$ & $\begin{array}{l}\text { Thematic projects and programs for the period from 2014 to 2020, } \\
\text { with a budget of } € 2.3 \text { billion, there are } 25 \text { subprogrammes in 3 } \\
\text { directions: outsourcing, competitiveness and doing business } \\
\text { culture. Small and medium-sized businesses, community } \\
\text { organizations, business associations, government agencies, } \\
\text { educational institutions can participate in programs. }\end{array}$ \\
\hline $\begin{array}{l}\text { United States Agency for } \\
\text { International } \\
\text { Development [22] }\end{array}$ & $\begin{array}{l}\text { Agrarian and Rural } \\
\text { Development Support } \\
\text { Program }\end{array}$ & $\begin{array}{l}\text { Lending and support for Ukrainian farmers for the period from } \\
2016 \text { to 2020, but USAID is responsible only for the financing of the } \\
\text { project, and its implementation is undertaken by the World } \\
\text { Council of Credit Unions (WOCCU). }\end{array}$ \\
\hline
\end{tabular}

Source: [17-22]

Today there are more and more tendencies in the sphere of financing small and medium business. Usually, they relate to investing in the idea from scratch, the socalled "startups". Some of the startups in many cases develop small and medium-sized businesses, and sometimes full-fledged corporations. To support and invest in such enterprises, special platforms are created, the most common form of which is business incubators.

Business incubator is an organizational innovation structure whose purpose is to create favorable conditions for the start-up development of small enterprises through providing them with a certain set of services and resources [23], which include: consulting; temporary free provision of premises; help in creating business plans; search for funding sources; financing of the project in the initial stages; market and competition research; scientific and technological equipment rental; providing legal, accounting services, etc. [24].

There are thousands of incubators in the world, mainly in highly developed countries (USA, UK, France, Germany). In recent years, structures of this type have begun to emerge in countries with a lower level of economic development. There are a number of centers that have emerged from projects in some African countries (eg Gabon, Morocco, Nigeria), Latin America (Mexico, Brazil, Argentina), as well as in Asian countries (Israel, Turkey, Malaysia, China).

In Ukraine, structures of this type also successfully operate. The Ukrainian Association of Business Incubators and Innovation Centers launched the project "Formation of an Information and Communication Environment for the Effective Development of Business Incubation in Ukraine" and "Creation of an Information and Communication Business Network for the Development of Business Incubation in the Kharkiv Region" The implementation of these projects takes place within the InfoDev program of the World Bank for Reconstruction and Development (WBRD). The main objective of the projects is to promote the development of business innovations in the sector of small and medium-sized enterprises, to improve the opportunities for business incubators through the effective use of information and communication technologies.

It is worth noting that the significant disadvantage of the existing infrastructure of innovation entrepreneurship in Ukraine is the uneven distribution of existing facilities by regions of Ukraine. Their main share is concentrated in the capital (among 255 existing 175 innovative structures operate in Kyiv), whereas in 18 of 27 regions of the country only 1-2 business incubators work.

The research of the legal framework for business incubators and innovation centers allows to highlight a number of key regulations, including: the Law of Ukraine "On State Support of Small Business" from 19 October 2000 [25] and "On innovation activity" on July 4, 2002 [23]. According to these laws, business incubators can be classified as innovative enterprises when developing, conducting, implementing and providing innovative products and (or) products or services, the amount of which in the money measurement exceeds 70 percent of its total volume. However, this legislative document does not clearly define the boundaries of the functioning of these innovative structures and measures for the proper support of them. In this regard, there is a need for a more specific state and regional policy to ensure the economic and legal conditions for the effective functioning of all the innovation infrastructure and, in particular, of business incubators.

The least well-known and widespread in Ukraine is a phenomenon called "business angels". In the economic environment, it is common sense to classify business angels as private investors who invest at their own risk in development projects, innovative startups with expectations of a certain outcome (income, influence, etc.) in the future. Unlike venture funds, the co-owners of which are institutional investors, business angels tend to invest their own funds. In addition, "angels" generally provide money free of charge, as well as their 
communications, experience, technology in exchange for a share, control in an investment object or in order to maintain relations with beneficiaries [26].

The Association of Private Investors of Ukraine (APIU), a member of the European Business Angel Network (EBAN), which unites are not only business angels, but also portfolio investors, as well as venture funds, is successfully operating in Ukraine. During the two years of the existence of this community in Ukraine, more than 80 projects were funded in the amount of more than $\$ 7$ million [27].

The development of small business is a very important factor for the country's economy, so the state must play an important role in its financing. State support for small businesses includes the provision of various subsidies, loans, the formation of state funds, the provision of tax rebates and benefits, etc. However, in Ukraine, financing of small enterprises within the state budget is carried out in insufficient volumes.

For example, in Japan, for the support and development of small businesses, special taxation was introduced for certain types of activities, a system of business insurance was established, business support for the latest developments and technologies was provided. The result of this activity is that Japan's industrial construction is $40 \%$ secured only by small businesses. Such state programs can serve as a model for implementation in Ukraine.

As a result of the analysis of scientific and statistical information on current sources of financing for small and medium-sized businesses in Ukraine, the following list of the main problems hindering its development was proposed: insufficient internal resources for selffinancing; restrictions on access to external sources of funding and investment attraction due to high requirements and lack of awareness; insufficient infrastructure development to support small and medium enterprises; unstable and unclear legislation in the field of small and medium enterprises development that limits the possibilities of business entities for long-term planning; insufficient development of the mechanism of cooperation between the state and small and medium business; low level of activity of small business entities in protecting their own interests; imperfection of the system of training and professional development of personnel for small and medium enterprises; high interest rates on bank lending and difficult loan conditions; undeveloped sphere of alternative sources of financing in Ukraine, such as leasing, factoring, venture funds; low level of awareness of entrepreneurs about existing funding programs; significant tax burden.

Therefore, in order to solve these problems, it is expedient to develop a set of measures that should be implemented both by the state and entrepreneurs. In modern conditions of management, it is necessary to improve the investment climate of small business, establish a transparent, stable and fair system of national legislation to attract a constant flow of foreign capital into Ukraine and attract funds from external sources of financing. Small and medium-sized entities, in turn, must step up their efforts to find alternative sources of funding and defend their interests in cases where they do not receive the support they deserve.

Conclusions and suggestions. The state of financing and state support for small and medium enterprises in Ukraine was analyzed, the advantages and disadvantages of traditional sources of funding were highlighted, and the possibility of using modern, alternative sources of financing for small and medium-sized businesses, which include factoring, leasing, venture capital funds, business incubators and "business angels" were emphasized.

A set of measures for improving the efficiency of small and medium-sized enterprises of Ukraine in the sphere of financing was developed and proposed. The recommended measures include: cheaper bank loans, which is possible during competent regulation of refinancing rates and minimizing the cost of loans from the central bank; encouraging banking and financial organizations to lend to small businesses by providing tax incentives; development of alternative methods of providing credits (for example, financial risk insurance, creation of guarantee funds or provision of state guarantees for loans for small and medium enterprises, reduction of tax burden for small and medium-sized businesses, granting of tax privileges; dissemination of information on alternative types of financing such as leasing, factoring, venture funds, the activities of international programs and funds, as well as private investors and business incubators.

\section{Література:}

1. Половен О. В. Особливості управління малим підприємством / О. В. Половен, К. Г. Петренко // Актуальні проблеми економіки. - 2009. - №6. - С. 131-135.

2. Румянцева С. В. Фінансування підприємств малого та середнього бізнесу / С .В. Румянцева // Цінні папери України. 2009. - №44. - C. 26.

3. Богун К. В. Удосконалення фінансової інфраструктури малого підприємництва в межах державно-приватного партнерства / К. В. Богун // Вісник Криворізького економічного інституту КНЕУ. - 2010. - № 3. - С. 104-108.

4. Буряк Л. Д. Фінансові ресурси підприємства // Фінанси України. - 2000. - №9. - С.23-27.

5. Кондратюк Т. В. Державна політика підтримки малого бізнесу: зміст і механізм реалізації / Т. В. Кондратюк // Вісник Української Академії державного управління при Президенті України. - 2001. - №4. - С. 111-118. 
6. Стричак Г. В. Державна підтримка підприємств малого та середнього бізнесу / Г. В. Стричак, О. Д. Франків // Науковий вісник БДФА. Економічні науки. - Вип. 2. - С. 471-478.

7. The Global Competitiveness Report 2017-2018 [Електронний ресурс]. - Режим доступу: https://www.weforum.org/reports/the-global-competitiveness-report-2017-2018

8. Офіційний сайт Приватбанку [Електронний ресурс]. - Режим доступу: https://privatbank.ua/

9. Офіційний сайт Райффайзен Банку Аваль [Електронний ресурс]. - Режим доступу: www.aval.ua

10. Офіційний сайт банку Креді Агріколь [Електронний ресурс]. - Режим доступу: https://credit-agricole.ua/

11. Офіційний сайт Кредобанку [Електронний ресурс]. - Режим доступу: https://www.kredobank.com.ua/

12. Офіційний сайт Першого Українського Міжнародного Банку [Електронний ресурс]. - Режим доступу: https://www.pumb.ua/

13. Офіційний сайт Укрексімбанку [Електронний ресурс]. - Режим доступу: https://www.eximb.com/ukr/personal/

14. Офіційний сайт Укрсиббанку [Електронний ресурс]. - Режим доступу: https://my.ukrsibbank.com

15. Офіційний сайт Ощадбанку [Електронний ресурс]. - Режим доступу: https://www.oschadbank.ua/ua/

16. Операції комерційних банків / Р. Коцовська, В. Ричаківська, Г. Табачук, Я. Грудзевич, М. Вознюк. - 4-те вид. - К. : Алерта, 2004. - 500 с.

17. Міжнародна фінансова корпорація (International Finance Corporation): проекти [Електронний ресурс]. - Режим доступу: https://ifcextapps.ifc.org/IFCExt/Pressroom/IFCPressRoom.nsf/0/1AB3F5169F4DE42485257FB70034A3B8

18. ЄБРP: фінансування проектів [Електронний ресурс]. - Режим

http://www.ebrd.com/russian/pages/workingwithus/projects/products/loans.shtml\#smaller

19. Німецько-український фонд: програми [Електронний ресурс] - Режим доступу: http://guf.gov.ua/uk/programi-1

20. Німецький державний банк розвитку: міжнародне фінансування [Електронний ресурс]. - Режим доступу: https://www.kfw.de/Internationale-Finanzierung/

21. Європейська програма підтримки малого та середнього бізнесу COSME. Europe's programme for small and mediumsized enterprises [Електронний ресурс]. - Режим доступу: http://ec.europa.eu/growth/smes/cosme/index_en.htm

22. Агентство США з міжнародного розвитку USAID в Україні [Електронний ресурс]. - Режим доступу: https://www.usaid.gov/uk/ukraine/our-work

23. Про інноваційну діяльність : закон України від 04.07.2002 р. №40-IV / Верховна Рада України // Відомості Верховної Ради України (ВВР), 2002, N 36, ст.266.

24. Васільєва Л. М. Бізнес-інкубатор як форма й елемент інноваційної інфраструктури [Електронний ресурс] / Л. М. Васільєва. - 2015. - Режим доступу: http://www.rusnauka.com/26_OINXXI_2009/Economics/52632.doc.htm.

25. Про державну підтримку малого підприємництва : закон України від 19.10.2000 р. № 2063-ІІІ // Відомості Верховної Ради України (ВВР) 2013, N 3, ст.23.

26. Hill, Brian E. and Power, Dee, Attracting Capital From Angels: How Their Money and Their Experience Can Help You Build a Successful Company, New York: John Wiley \& Sons, 2002.

27. Ульяницька О. В. Бізнес-ангели як альтернативна форма фінансування підприємницького сектору в Україні [Електронний ресурс] / О. В. Ульяницька, Т. В. Ярошенко. - Режим доступу: http://www.nbuv. gov.ua/portal/Soc_Gum/Mre/2009_2/1.2.2.pdf.

\section{References:}

1. Poloven, O. V. and Petrenko, K. G. (2009). "Features of management of small enterprise", Aktualni problemy ekonomiky, vol.6, pp. 131-135.

2. Rumyantseva, S. V. (2009). "Financing of Small and Medium Enterprises", Cinni papery Ukrainy, vol. 44, p. 26.

3. Bogun, K.V. (2010). "The improvement of financial infrastructure of small business within the framework of public-private partnership", Visnyk Kryvorizkoho ekonomichnoho instytutu KNEU, vol. 3, pp. 104-108.

4. Buryak, L. D. (2000). "Financial resources of the enterprise", Finansy Ukrainy, vol. 9, pp.23-27.

5. Kondratyuk, T. V. (2001). "State policy of small business support: content and mechanism of realization", Visnyk Ukrainskoi Akademii derzhavnoho upravlinnya pry Prezydenti Ukrainy, vol. 4, pp. 111-118.

6. Strychak, G. V. and Frankiv, O. D. (2008). "State support of small and medium enterprises", Naukovyi visnyk BDFA, vol. 2, pp. $471-478$.

7. The Global Competitiveness Report 2017-2018 [Online], available at: https://www.weforum.org/reports/the-globalcompetitiveness-report-2017-2018 (Accessed 01 October 2018).

8. Official site of Privatbank, available at: https://privatbank.ua/ (Accessed 01 October 2018).

9. Official website of Raiffeisen Bank Aval, available at: www.aval.ua (Accessed 01 October 2018).

10. Official website of Credit Agricole Bank, available at: https://credit-agricole.ua/ (Accessed 01 October 2018).

11. Official site of Kredobank, available at: https://www.kredobank.com.ua/ (Accessed 01 October 2018).

12. Official website of the First Ukrainian International Bank, available at: https://www.pumb.ua/.

13. Official Site of Ukreximbank, available at: https://www.eximb.com/ukr/personal/ (Accessed 01 October 2018).

14. Official site of Ukrsibbank, available at: https://my.ukrsibbank.com (Accessed 01 October 2018).

15. Official site of Oshchadbank, available at: https://www.oschadbank.ua/ua/ (Accessed 01 October 2018).

16. Kotsovska, R. Rychakivska, V. Tabachuk, G. Grudzevich, Y. and Voznyuk, M. (2004). Operacii komerciynych bankiv, Kyiv, Ukraine. 
Електронне наукове фахове видання з економічних наук “Modern Economics», №11 (2018), 58-65 https://modecon.mnau.edu.ua | ISSN 2521-6392

\footnotetext{
17. Official site of International Finance Corporation: Projects, available at: https://ifcextapps.ifc.org/IFCExt/Pressroom/IFCPressRoom.nsf/0/1AB3F5169F4DE42485257FB70034A3B8 (Accessed 01 October 2018).

18. Official site of European Bank for Reconstruction and Development: Project Financing, available at: http://www.ebrd.com/russian/pages/workingwithus/projects/products/loans.shtml\#smaller (Accessed 01 October 2018).

19. Official site of German-Ukrainian Foundation: Programs, available at: http://guf.gov.ua/ru/programi-1 (Accessed 01 October 2018).

20. Official site of German State Development Bank: International Financing, available at: https://www.kfw.de/InternationaleFinanzierung/ (Accessed 01 October 2018).

21. Official site of European Small and Medium Business Support Program available at: http://ec.europa.eu/growth/smes/cosme/index_en.htm (Accessed 01 October 2018).

22. Official site of United States Agency for International Development USAID in Ukraine, available at: https://www.usaid.gov/uk/ukraine/our-work (Accessed 01 October 2018).

23. The Verkhovna Rada of Ukraine (2002), The Law of Ukraine "On innovation activity", Visnyk Verkhovnoi Rady Ukainy, p.266.

24. Vasilieva, L. M. (2015). "Business Incubator as a Form and Element of Innovation Infrastructure", available at: http://www.rusnauka.com/26_OINXXI_2009/Economics/52632.doc.htm (Accessed 01 October 2018).

25. The Verkhovna Rada of Ukraine (2013). The Law of Ukraine "On State Support to Small Entrepreneurship", Visnyk Verkhovnoi Rady Ukainy, vol. 3, p.23.

26. Hill, B. E. and Power, D., Attracting Capital From Angels: How They Make Money and Their Experience Can Help You Build A Successful Company, New York: John Wiley \& Sons, 2002.

27. Ulyanyts'ka, O. V. and Yaroshenko, T. V. (2009). "Business angels as an alternative form of financing of the entrepreneurial sector in Ukraine", available at: http: //www.nbuv. gov.ua/portal/Soc_Gum/Mre/2009_2/1.2.2.pdf (Accessed 01 October 2018).
} 